\title{
Effects of metamorphosis timing and the larval growth rate on the latitudinal distribution of sympatric freshwater eels, Anguilla japonica and A. marmorata, in the western North Pacific
}

\author{
Nico Jose Leander ${ }^{1}$, Wann-Nian Tzeng ${ }^{1,2^{*}}$, Nian-Tzu Yeh ${ }^{1}$, Kang-Ning Shen ${ }^{1,2}$ and Yu-San Han ${ }^{1}$
}

\begin{abstract}
Background: Early life history traits of the temperate eel Anguilla japonica and tropical eel Anguilla marmorata were examined to determine the possible reason why these two species have similar spawning areas and oceanic larval transport in the North Equatorial Current and yet are recruited to different but partly overlapping continental growth habitats in northern East Asia. To understand the segregative migration of these two sympatric eel species, their glass eels were collected from nine estuaries in the Philippines, Taiwan, Japan, and China. The age at metamorphosis from leptocephalus to glass eel $\left(T_{m}\right)$, the age at estuarine arrival $\left(T_{t}\right)$, the time between metamorphosis and estuarine arrival $\left(T_{t-m}\right)$, and the growth rate $\left(G_{t}\right)$ of glass eels were calculated from daily growth increments in their otoliths.
\end{abstract}

Results: Results indicated that the $G_{\mathrm{t}}$ was faster and the $T_{\mathrm{m}}$ was younger in A. marmorata than in A. japonica. On the other hand, fish length and the $T_{\mathrm{t}}$ at estuarine arrival were larger in A. japonica than in A. marmorata, indicating that elvers of $A$. japonica experience a longer oceanic drift than those of $A$. marmorata. In addition, the $T_{t-m}$ also indicated that A. japonica experienced a longer coastal migration than A. marmorata.

Conclusion: This study validated that the $T_{m}$ and $G_{t}$ seem to play important roles in the segregative migration and latitudinal distribution of these two sympatric freshwater eel species in the northwestern Pacific.

Keywords: Otolith; Daily growth increment; Japanese eel; Giant mottled eel; Larval migration

\section{Background}

Due to their mysterious life history and economic importance, freshwater eels (Anguilla spp.) have been the focus of much scientific research for decades. However, despite these efforts, most of the aspects of their early life history are still not completely understood. In the past three decades, dramatic declines in glass eel recruitment of temperate species like the American (Anguilla rostrata), European (Anguilla anguilla), Japanese (Anguil la japonica), and Australian (Anguilla australis) eels have raised concerns (Jellyman et al. 2000; Hoyle and Jellyman 2002; Tatsukawa 2003; Dekker 2008; Richkus

\footnotetext{
* Correspondence: wnt@ntu.edu.tw

'Institute of Fisheries Science, College of Life Science, National Taiwan University, Taipei 10617, Taiwan

${ }^{2}$ Department of Environmental Biology and Fisheries Science, National Taiwan Ocean University, Keelung 20224, Taiwan
}

and Whalen 2000). The reasons for the declines are unclear but are probably due to reductions in spawning stocks (Jansen et al. 2007; Winter et al. 2007; Clevestam et al. 2011), overfishing (Tzeng et al. 1995; Moriarty and Dekker 1997; Jellyman et al. 2000; Hoyle and Jellyman 2002; Briand et al. 2003; Chisnall et al. 2003; Dekker 2003; Lin et al. 2010), growth habitat and access reductions (Busch et al. 1998; Haro et al. 2000; McCleave 2001; McCleave and Jellyman 2004; Verreault et al. 2004; Graynoth et al. 2008), pollution (Amiard-Triquet et al. 1988; Robinet and Feunteun 2002; Palstra et al. 2006; van Ginneken et al. 2009), swim bladder and gill parasites and viral infections (Haenen et al. 2002; Szekely et al. 2002; Kirk 2003; Sures and Knopf 2004; van Ginniken et al. 2005; Han et al. 2008, 2009a; Sasal et al. 2008; Parker et al. 2011), global climate change 
(Castonguay et al. 1994; Kimura et al. 2001; Casselman 2002; Knights 2003; Han et al. 2006, 2009b; Friedland et al. 2007; August and Hicks 2008; Bonhommeau et al. 2008; Miller et al. 2009), and the solar cycle (Tzeng et al. 2012). To understand the declines, it is necessary to study the early life history of anguillid eels. The life history of eels during the continental growth phase is well documented, but knowledge of the marine larval life stage from the spawning ground to the estuary is still fragmented (McCleave 1993; Cheng and Tzeng 1996; Wang and Tzeng 2000; Tzeng 2003; Edeline et al. 2009; Miller 2009). Early life history information is very important because it is a key factor in understanding possible reasons for recruitment success or failure of anguillid eels and also for their artificial propagation.

The temperate eel A. japonica and tropical eel Anguil la marmorata are just two dominant species of anguillid eels in Taiwan, the distribution and recruitment season of which differ (Tzeng 1982; Tzeng and Tabeta 1983; Kuroki et al. 2009; Leander et al. 2012). Both species spawn in waters west of the Mariana Islands in the Pacific Ocean (Kuroki et al. 2009; Tsukamoto et al. 2011), and their marine larvae or leptocephali are transported westward by the North Equatorial Current (NEC) from their spawning grounds to the continental shelf of the northwestern Pacific. Furthermore, $A$. marmorata larvae drift in both the northwardly flowing Kuroshio Current (KC) and the southwardly flowing Mindanao Current, while $A$. japonica larvae only enters the northwardly flowing $\mathrm{KC}$ that transports them to East Asia, particularly Taiwan, China, Japan, and Korea. Why $A$. japonica larvae only enter the KC region, while $A$. marmorata, after being transported by the NEC, can enter both the northwardly flowing $\mathrm{KC}$ (which carries them to eastern China, southern Japan, and Korea) and the southwardly flowing Mindanao Current (that carries them to recruitment areas in northern Indonesia, the Philippines, and Taiwan), is still unclear (Kuroki et al. $\times 2009$ ). Recently, Han et al. (2012) pointed out that recruitment temperature preferences and oceanic current systems control the distinct biogeography of $A$. japonica and $A$. marmorata. Aside from these abiotic parameters, biological factors should also be taken into consideration in explaining this ecological discrepancy, but the early life histories of these two species particularly during the oceanic phase are not yet fully understood, especially that of $A$. marmorata. Upon reaching continental waters, it was also found that their distributions in estuaries also geographically differed. For example, A. japonica is abundant along the northern and western coasts of Taiwan, while $A$. marmorata is abundant along the southern and eastern coasts (Leander et al. 2012; Han et al. 2012). In addition, it was also observed that in the same river system, A. marmorata occupied the upper reaches while $A$. japonica occupied the lower reaches (Shiao et al. 2003). These observations indicated that microhabitats of these species evolved differently to avoid interspecific competition for food and space, although their distribution areas overlap. Also, genetic (mitochondrial DNA and microsatellites) and morphological (total number of vertebrae) studies suggested that $A$. marmorata has at least four or five different spawning populations in the entire Indo-Pacific region: the North Pacific (Sulawesi/northern Indonesia, the Philippines, Taiwan, China, Korea, and Japan), South Pacific (Fiji, New Caledonia, and Papua New Guinea), Indian Ocean (Madagascar, Reunion, and Sumatra), Micronesia (Guam, Palau, and the Caroline Islands), and Tahiti (Ishikawa 1998; Ishikawa et al. 2004; Minegishi et al. 2008; Watanabe et al. 2008, 2009).

Recent studies specifically on A. japonica (Tzeng 2003) indicated that the otolith microstructure and microchemistry can provide some clues to understanding the early life history of fish during their migration from spawning grounds until recruitment, but little is known about the early life history of most tropical species, particularly A. marmorata (Sugeha et al. 2001a; Arai et al. 2002a, b; Miller et al. 2002; Shiao et al. 2003). Also, it was found that the age at metamorphosis from the leptocephalus to glass eel can be determined by changes in otolith microstructures and in strontium/calcium $(\mathrm{Sr} / \mathrm{Ca})$ ratios in daily growth increments (DGIs) of otoliths (Tzeng and Tsai 1992, 1994; Tzeng 1995). The $\mathrm{Sr}$ concentration in the otolith decreases dramatically during metamorphosis, and a visible metamorphosis check (MC) is also deposited during this period. Since the growth increments of otoliths of anguillid eels are deposited on a daily basis (Martin 1995; Arai et al. 2000; Cieri and McCleave 2001; Sugeha et al. 2001b), the age of the leptocephalus at metamorphosis can be determined from the number of DGIs from the primordium and the $\mathrm{MC}$ where the increment pattern and $\mathrm{Sr} / \mathrm{Ca}$ ratios dramatically change (Tzeng and Tsai 1994; Tzeng 1996; Arai et al. 1999a). In other words, since the structure of growth increments in the anguillid eel's otoliths change with growth and growth checks appear in every life history stage transition, the duration of each life history stage can be determined by counting the DGIs in each section of an otolith.

In the present study, we reviewed the early life history of the temperate eel $A$. japonica which was studied by Cheng and Tzeng (1996). Meanwhile, the early life history of the tropical eel A. marmorata collected from three estuaries in the Philippines, Taiwan, and Japan was also studied following the techniques used for $A$. japonica in a previous study (Cheng and Tzeng 1996). Only the North Pacific population of A. marmorata was considered in the present study. Based on information such 
as the timing of metamorphosis from leptocephalus to glass eel, the inshore migration period of the glass eel, the age and size at estuarine arrival, and growth rates of leptocephali and glass eels, we attempted to understand the evolution and adaptation of these two sympatric species in their distribution areas. Segregative migration and the recruitment mechanism of these two species in the northwestern Pacific were also addressed.

\section{Methods}

\section{Fish sample collection}

In total, 168 A. marmorata glass eels were collected from the estuaries of the Hsiukuluan River, eastern Taiwan $(n=86)$ on 20 May 2008; the Cagayan River, northern Philippines $(n=45)$ on 19 May 2008; and the Kurio River, southern Japan $(n=37)$ on 6 June 1996 (Table 1, Figure 1). Procedures of fish handling were carried out in accordance with the ethical standards and guidelines for animal experiments of National Taiwan University. All specimens were immediately preserved in 95\% ethanol after measuring the total lengths (TLs) to the nearest millimeter $(\mathrm{mm})$. On the other hand, $A$. japonica specimens examined from a previous study
(Cheng and Tzeng 1996) were collected from the estuaries of the Tungkang River, southern Taiwan $(n=60)$ on 30 December 1992 and 24 March 1993; the Shuangshi River, northern Taiwan $(n=60)$ on 20 December 1992 and 17 February 1993; the Mingchiang River, eastern China $(n=30)$ on 1 March 1993; the Chyantarng River, eastern China $(n=30)$ on 17 February 1993; the Yalu River, northern China $(n=30)$ on 3 May 1993; and the Ichinomiya River, eastern Japan $(n=30)$ on 10 January 1994 (Table 1, Figure 1).

\section{Determination of the developmental stages of the fish samples}

Developmental stages of eel samples from the glass eel to the elver stages were determined according to the extent (or absence) of skin pigmentation over the head, tail, and other body regions following the methods described by Strubberg (1913), Bertin (1956), and Tesch (1977, 2003). Postmetamorphic juveniles were subclassified into stages $\mathrm{V}_{\mathrm{A}}, \mathrm{V}_{\mathrm{B}}, \mathrm{VI}_{\mathrm{A} 1}, \mathrm{VI}_{\mathrm{A} 2}, \mathrm{VI}_{\mathrm{A} 3}, \mathrm{VI}_{\mathrm{A} 4}, \mathrm{VI}_{\mathrm{B}}$, and VII. Juveniles up to stage $\mathrm{VI}_{\mathrm{A} 2}$ were classified as glass eels, while those in stages $\mathrm{VI}_{\mathrm{A} 3}$ and $\mathrm{VI}_{\mathrm{A} 4}$ were in the transition stage to elvers, which become fully pigmented

Table 1 Sampling and age information of Anguilla japonica and Anguilla marmorata specimens analyzed in this study

\begin{tabular}{|c|c|c|c|c|c|c|c|}
\hline \multirow[t]{2}{*}{ Species } & \multirow[t]{2}{*}{ Sampling site } & \multirow[t]{2}{*}{ Sampling date } & \multirow[t]{2}{*}{ Number } & \multirow[t]{2}{*}{ Total length (mm) } & \multicolumn{3}{|c|}{ Age (days) } \\
\hline & & & & & $T_{\mathrm{m}}$ & $T_{\mathrm{t}}$ & $T_{\mathrm{t}-\mathrm{m}}$ \\
\hline \multirow[t]{8}{*}{ A. japonica } & $\begin{array}{l}\text { Tungkang River, } \\
\text { Taiwan }\end{array}$ & $\begin{array}{c}30 \text { December } \\
1992\end{array}$ & $30(16)$ & $57.0 \pm 2.0$ & $138.7 \pm 14.3$ & $177.7 \pm 17.8$ & $39.0 \pm 11.2$ \\
\hline & & 24 March 93 & $30(14)$ & $56.1 \pm 2.4$ & $134.0 \pm 14.1$ & $174.4 \pm 17.9$ & $40.4 \pm 11.0$ \\
\hline & $\begin{array}{c}\text { Shuangshi River, } \\
\text { Taiwan }\end{array}$ & $\begin{array}{l}20 \text { December } \\
92\end{array}$ & $30(12)$ & $56.8 \pm 2.3$ & $135.7 \pm 16.6$ & $175.0 \pm 20.9$ & $39.5 \pm 9.2$ \\
\hline & & 17 February 93 & $30(13)$ & $55.9 \pm 2.2$ & $128.9 \pm 14.6$ & $174.4 \pm 17.7$ & $45.5 \pm 13.4$ \\
\hline & $\begin{array}{l}\text { Mingchiang River, } \\
\text { China }\end{array}$ & 1 March 93 & $30(20)$ & $55.1 \pm 1.9$ & $139.6 \pm 10.1$ & $172.1 \pm 14.1$ & $32.5 \pm 7.7$ \\
\hline & $\begin{array}{c}\text { Chyantarng River, } \\
\text { China }\end{array}$ & 17 February 93 & $30(23)$ & $55.6 \pm 1.9$ & $148.1 \pm 14.7$ & $194.9 \pm 18.6$ & $46.8 \pm 8.9$ \\
\hline & Yalu River, China & 3 May 93 & $30(23)$ & $58.3 \pm 1.8$ & $157.4 \pm 16.1$ & $199.3 \pm 15.6$ & $41.9 \pm 3.9$ \\
\hline & $\begin{array}{l}\text { Ichinomiya River, } \\
\text { Japan }\end{array}$ & 10 January 94 & $30(10)$ & $57.4 \pm 2.3$ & $143.3 \pm 7.9$ & $186.6 \pm 7.0$ & $43.3 \pm 5.2$ \\
\hline Overall $\left(\mu_{1}\right)$ & & & $\begin{array}{c}240 \\
(131)\end{array}$ & $56.5 \pm 2.1$ & $140.7 \pm 13.6$ & $181.8 \pm 16.2$ & $41.1 \pm 8.8$ \\
\hline \multirow[t]{3}{*}{ A. marmorata } & $\begin{array}{c}\text { Cagayan River, the } \\
\text { Philippines }\end{array}$ & 19 May 08 & $45(13)$ & $49.5 \pm 1.5$ & $110.4 \pm 12.8$ & $144.8 \pm 14.2$ & $34.3 \pm 7.9$ \\
\hline & $\begin{array}{l}\text { Hsiukuluan River, } \\
\text { Taiwan }\end{array}$ & 20 May 08 & $86(13)$ & $51.6 \pm 1.6$ & $112.4 \pm 12.3$ & $134.0 \pm 15.4$ & $22.6 \pm 6.6$ \\
\hline & Kurio River, Japan & 6 June 96 & 37 (15) & $46.7 \pm 1.7$ & $117.7 \pm 16.8$ & $145.0 \pm 17.8$ & $27.3 \pm 8.9$ \\
\hline Overall $(\mu 2)$ & & & $168(41)$ & $49.3 \pm 1.6$ & $113.5 \pm 13.0$ & $141.6 \pm 15.8$ & $28.1 \pm 7.8$ \\
\hline $\begin{array}{l}\text { Difference } \\
\left(\mu_{1-} \mu_{2)}\right.\end{array}$ & & & & 7.2 & 27.2 & 40.2 & 13.0 \\
\hline Significance & & & & $\begin{array}{c}\text { A. japonica }>A . \\
\text { marmorata }\end{array}$ & $\begin{array}{c}\text { A. japonica }>A \text {. } \\
\text { marmorata }\end{array}$ & $\begin{array}{l}\text { A. japonica }>A \text {. } \\
\text { marmorata }\end{array}$ & $\begin{array}{c}\text { A. japonica }>A \text {. } \\
\text { marmorata }\end{array}$ \\
\hline
\end{tabular}

${ }^{a}$ Cheng and Tzeng (1996). Values inside parentheses indicate the number of individuals used for aging. Daily age of glass eels at the estuary $\left(T_{t}\right)$, daily age at metamorphosis from leptocephalus to glass eel $\left(T_{\mathrm{m}}\right)$ and the time between the metamorphosis check and estuarine arrival $\left(T_{\mathrm{t}-\mathrm{m}}\right)$. 


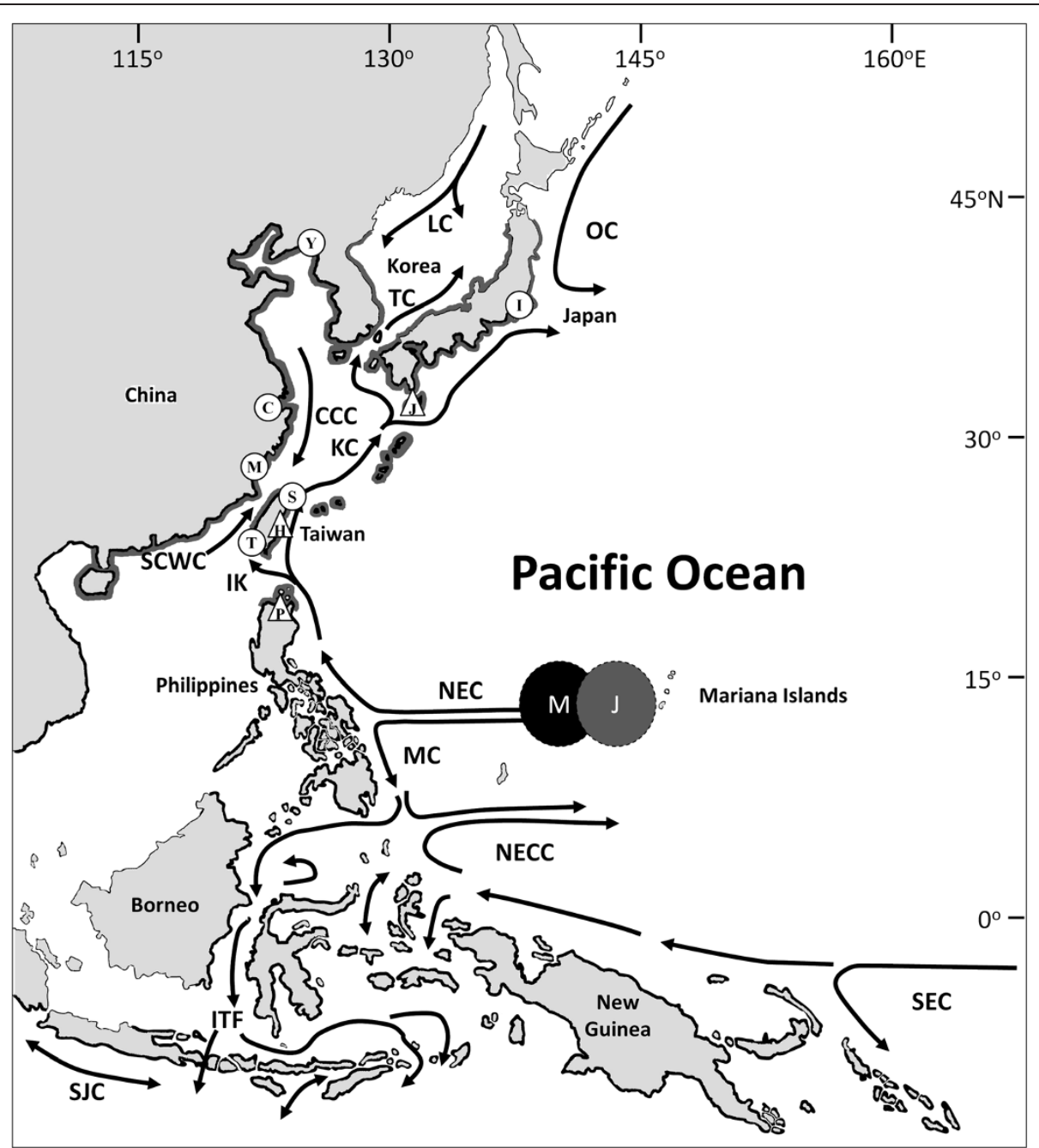

Figure 1 Map showing the geographic distributions of Anguilla japonica and A. marmorata. Map showing the geographic distributions of Anguilla japonica (thick gray lines on the coastlines) and A. marmorata (thick black lines on the coastlines) in East Asia and collection sites of samples analyzed in this study (white triangle, A. marmorata; white circle, A. japonica; Cheng and Tzeng 1996). General patterns of current systems in the western North Pacific and central Indonesian seas (adapted from Nitani 1972 and Lukas et al. 1991) and spawning grounds of A. japonica (gray circle with the letter J) and A. marmorata (black circle with the letter M) (Kuroki et al. 2009; Tsukamoto et al. 2011) are also shown. Sampling locations: Tungkang River (T) and Shuangshi River (S), Taiwan; Mingchiang River (M), Chyantarng River (C), and Yalu River (Y), China; Ichinomiya River (I), Japan; Cagayan River (P), the Philippines; Hsiukuluan River (H), Taiwan; and Kurio River (J), Japan. NEC, North Equatorial Current; KC, Kuroshio Current; OC, Oyashio Current; TS, Tsushima Current; CCC, China Coastal Current; SCSWC, South China Sea Warm Current; IK, Intruded Kuroshio; MC, Mindanao Current; NECC, North Equatorial Counter Current; SEC, South Equatorial Current.

at stage $\mathrm{VI}_{\mathrm{B}}$ stage (Fukuda 2010). Stage $\mathrm{VI}_{\mathrm{B}}$ indicates the end of pigmentation, while stage VII represents the fully pigmented, benthic elver (Tabeta and Mochioka 2003).

\section{Otolith preparation for microchemical analyses}

Sagittal otoliths, the largest of the three pairs of otoliths in the inner ear, were extracted and embedded in epofix resin. The embedded otolith was ground and polished with a grinding machine until the primordium was exposed. $\mathrm{Sr}$ and $\mathrm{Ca}$ concentrations were measured from the primordium to the otolith edge at $10-\mu \mathrm{m}$ intervals with an electron beam of $5 \mu \mathrm{m}$ in diameter, using an electron probe microanalyzer equipped with a wavelength-dispersive spectrometer (WDS-EPMA, JEOL JX A-8900R, Tokyo, Japan). The accelerating voltage was set to $15 \mathrm{kV}$ and the probe current to $3 \mathrm{nA}$. The peak concentration of $\mathrm{Sr}$ was counted for $80 \mathrm{~s}$ with background measurements for $20 \mathrm{~s}$ on each side. On the other hand, the peak concentration of $\mathrm{Ca}$ was counted for $20 \mathrm{~s}$ and each background for $10 \mathrm{~s}$. Strontianite $\left(\mathrm{SrCO}_{3}\right.$, USNM-R10065) and calcite $\left(\mathrm{CaCo}_{3}\right.$, USNM36321) from the Department of Mineral Sciences, National Museum of Natural History, Smithsonian Institution, Washington, D.C., USA, were used as standards 
to calibrate the $\mathrm{Sr}$ and $\mathrm{Ca}$ concentration in eel otoliths. After the microchemical analysis, the otolith was polished to remove the carbon layer and etched for 1 to 2 min with 5\% ethylenediaminetetraacetic acid (EDTA) to reveal the DGIs. Procedures for embedding, sectioning, polishing, and etching otoliths to reveal the DGIs and measuring the otolith $\mathrm{Sr} / \mathrm{Ca}$ ratios followed those described in previous studies by Tzeng $(1990,1996)$, while the procedure for measuring the otolith $\mathrm{Sr} / \mathrm{Ca}$ ratios followed that of Tzeng and Tsai (1994).

\section{Otolith microstructural analyses}

The DGIs in the otoliths were examined from scanning electron microscopic (SEM) photographs at various magnifications $(\times 200, \times 1,000$, and $\times 1,500)$. Both the DGIs and $\mathrm{Sr} / \mathrm{Ca}$ ratios were measured along the longest otolith axis. Growth checks of each early life history event or transition recorded in the otoliths were identified using both otolith microstructures (the DGI width) and microchemistry ( $\mathrm{Sr} / \mathrm{Ca}$ ratios). DGIs in each of the developmental stages and otolith radius were counted and measured from these landmarks as shown in Figure 2. Because otolith increments in A. marmorata and $A$. japonica were confirmed to be deposited on a daily basis (Tabeta et al. 1987; Umezawa et al. 1989; Sugeha et al. 2001b), the increment number was considered as the daily age in each individual examined in the present study. The drastic change in otolith $\mathrm{Sr} / \mathrm{Ca}$ from the primordium to the otolith edge coincided with major life history events in the life of the young eels, like first feeding, metamorphosis, etc., as reported in previous studies for both temperate and tropical anguillid species (Tzeng and Tsai 1992, 1994; Otake et al. 1994; Tzeng 1996; Arai et al. 1997, 1999a, b, c; Cieri and McCleave 2001; Marui et al. 2001). The age of the leptocephalus at the onset of metamorphosis $\left(T_{\mathrm{m}}\right)$ was determined from the number of DGIs between the primordium $(\mathrm{P})$ and $\mathrm{MC}$ where the increment pattern and $\mathrm{Sr} / \mathrm{Ca}$ ratios dramatically changed (Otake et al. 1994, 1997; Tzeng and Tsai 1994; Tzeng 1995; Kuroki et al. 2005; Arai et al. 2002a). To estimate the $T_{\mathrm{m}}, 13$ days (adjustment factor, $N_{0}$ ) was added to the number of DGIs because a previous study found that no increment was deposited in the core of the otolith during the yolk-sac stage, and otolith growth increment deposition only commences once a larva begins feeding 13 days after hatching (Tanaka et al. 1995). The duration of the metamorphosis stage was determined by counting the number of DGIs between the onset of a marked increase in the otolith increment width and its maximum peak. The amount of time between metamorphosis and estuarine arrival $\left(T_{\mathrm{t}-\mathrm{m}}\right)$ was calculated by counting the number of DGIs between the $\mathrm{MC}$ and the edge of the otolith, while the age at recruitment $\left(T_{\mathrm{t}}\right)$ was determined as the number of DGIs between the hatch check and otolith edge. On the other hand, radii from the primordium to the first feeding check $\left(R_{\mathrm{f}}\right)$, to the MC $\left(R_{\mathrm{m}}\right)$, and to the otolith edge $\left(R_{\mathrm{t}}\right)$ and the distance from the MC to the otolith edge $\left(R_{\mathrm{t}-\mathrm{m}}\right)$ were measured along the longest sagittal axis of the otolith (Figure 2). Otolith growth rates at different developmental stages were calculated by dividing the otolith radius by the DGI (Equations 1 to 3). Because increments near the metamorphosis zone in the otolith of some samples were often diffusive and obscure, the daily age of samples without counting DGIs was calculated from both the otolith growth rate and otolith radius (Equations 4 to 6 ):

$$
\begin{aligned}
& \text { Overall growth rate of otolith, } G_{\mathrm{t}}=\frac{R_{\mathrm{t}}}{T_{\mathrm{t}}} \\
& \text { Early growth rate of otolith, } G_{\mathrm{m}}=\frac{R_{\mathrm{m}}}{T_{\mathrm{m}}} \\
& \text { Estuarine growth rate of otolith, } G_{\mathrm{t}-\mathrm{m}}=\frac{R_{\mathrm{t}-\mathrm{m}}}{T_{\mathrm{t}-\mathrm{m}}} \\
& T_{\mathrm{m}}=\frac{R_{\mathrm{m}}-R_{\mathrm{f}}}{G_{\mathrm{m}}}+N_{0} \\
& T_{\mathrm{t}-\mathrm{m}}=\frac{T_{\mathrm{t}-\mathrm{m}}}{G_{\mathrm{t}-\mathrm{m}}} \\
& T_{\mathrm{t}}=T_{\mathrm{m}}+T_{\mathrm{t}-\mathrm{m}}
\end{aligned}
$$

where $G_{\mathrm{m}}$ and $G_{\mathrm{t}-\mathrm{m}}$ were obtained from Equations 2 and 3 , and $N_{0}$ is the adjustment factor (13 days) for the yolk-sac stage duration. Differences in the total length (TL), daily age, and growth rate between A. japonica and A. marmorata were tested by an analysis of variance (ANOVA) as implemented in SigmaStat vers. 3.1 (Systat Software, San Jose, CA, USA).

\section{DGIs and growth checks in the otoliths}

Otolith microstructures between the temperate A. japonica and tropical $A$. marmorata were fundamentally the same (Arai et al. 2001a). DGIs in otoliths of glass eels are composed of two layers called the incremental (L) and discontinuous (D) zones, which respectively appeared to be light and dark as revealed by the SEM photo in Figure 2a. The L-zone is rich in calcium carbonate $\left(\mathrm{CaCO}_{3}\right)$, while the D-zone is very rich in protein but poor in calcium. When etched with hydrochloric acid $(\mathrm{HCl})$ or EDTA and viewed under an SEM, the L-zone appeared elevated while the D-zone appeared as a ridge. A single DGI is usually composed of an L-zone and a D-zone and is generally deposited on a daily basis. Near the otolith edge, a distinct growth check called the elver check was found (Figure 2b). The elver check was deposited in the elver stage during its migration from seawater to freshwater. It also marks the transition from 


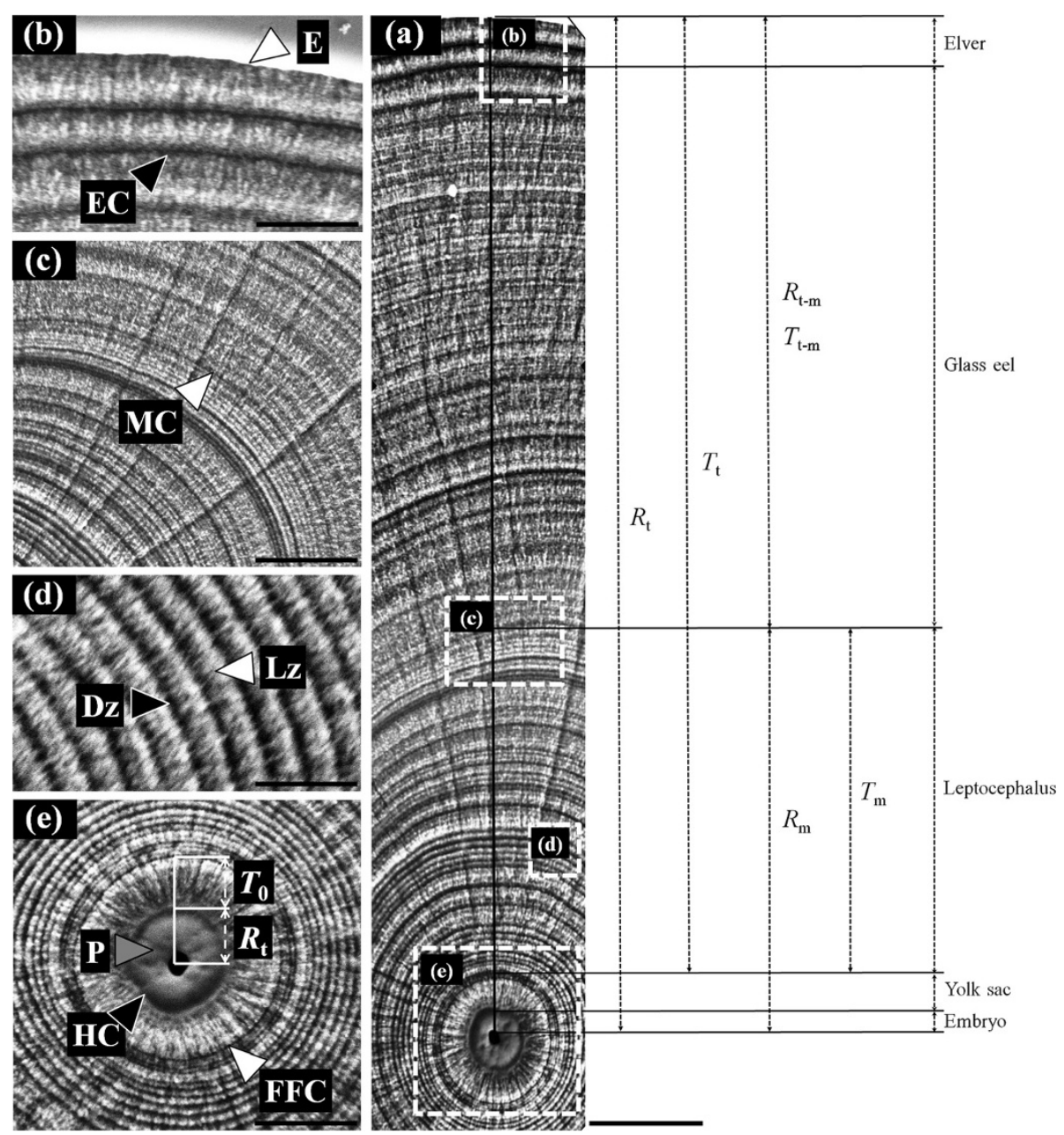

Figure 2 SEM photographs showing daily growth increments (DGIs) and growth checks in an Anguilla marmorata otolith. (a) SEM photographs showing daily growth increments (DGIs) and growth checks in an otolith of an Anguilla marmorata elver and measurements of otolith radii $(R)$ and counts of DGls (T) according to the developmental stage. Scale bar $=20 \mu \mathrm{m}$. (b to e) Magnified portions of (a) showing (b) estuarine check (EC) and the otolith edge (e), (c) metamorphosis check (MC), (d) discontinuous (dark band, Dz) and increment (light band, Lz) zones, and (e) the primordium (P), hatching check ( $\mathrm{HC}$ ), and first feeding check (FFC). $R_{\mathrm{f}}, R_{\mathrm{m}}, R_{\mathrm{t}}$, radii from the primordium to the FFC, MC, and $\mathrm{OE}$, respectively; $R_{\mathrm{t}-\mathrm{m}}$, distance from the $\mathrm{MC}$ to the $\mathrm{OE} ; \mathrm{OL}$, otolith length; $T_{\mathrm{m}}, T_{\mathrm{t}}, T_{\mathrm{t}-\mathrm{m}}$, counts of DGls on radii of $R_{\mathrm{m}}$ and $R_{\mathrm{t}}$ and the section $R_{\mathrm{t}-\mathrm{m}}$ between the $M C$ and $\mathrm{OE}$, respectively.

the glass eel to the elver stage. On the other hand, DGIs at the beginning of the leptocephalus stage were wide and clear but became very diffuse and obscure and almost uncountable near the metamorphosis area (Figure 2c). This indicated that the leptocephalus grew fast during the early developmental stage, then gradually slowed down and reached an asymptotic length before metamorphosis. Thus, an MC was deposited at the transition from the leptocephalus to glass eel stage. After the $\mathrm{MC}$ to the otolith edge, the DGIs became wider, indicating that growth speeded up after metamorphosis. The $\mathrm{P}$ in the otolith of the elver was an amorphous structure which appeared as a deep hole after etching with $\mathrm{HCl}$ or EDTA (Figure 2d). Distinct concentric growth increments and check rings were observed around the $\mathrm{P}$ that marked hatching $(\mathrm{HC})$ and first feeding (FFC). The $\mathrm{HC}$ appeared as a deep circular grove surrounding the $\mathrm{P}$. between the HC and FFC, no distinct DGI was discernible (Figure 2d). From the $\mathrm{P}$ to the otolith edge, the change in DGI widths revealed the growth history of the eel as it migrated from the oceanic spawning ground until it was recruited to the estuary (Figure 2e). Also, the DGIs recorded different life history and developmental stage transitions.

\section{Larval dispersal distance and age at metamorphosis}

To determine the effect of metamorphosis from leptocephalus to glass eel on the larval dispersal distance, the age at metamorphosis of glass eels from each of the sampling locations in East Asia were compared in 
relation to their distances from the spawning grounds of both species in waters west of the Mariana Islands (12 to $17^{\circ} \mathrm{N}, 131$ to $143^{\circ} \mathrm{E}$; Kuroki et al. 2009).

\section{Results}

Differences in size and age at estuarine arrival between species and among locations

TLs of A. japonica glass eels at estuarine arrival ranged from $55.1 \pm 1.9 \mathrm{~mm}$ in the Mingchiang River, southeastern China to $58.3 \pm 11.3 \mathrm{~mm}$ in the Yalu River near the border of China and North Korea (Table 1), while those of $A$. marmorata ranged from $46.7 \pm 1.7 \mathrm{~mm}$ in the Kurio River, southern Japan to $51.6 \pm 1.6 \mathrm{~mm}$ in the Hsiukuluan River, eastern Taiwan. Within the same species, A. japonica glass eels from the Yalu River were significantly longer than those from the other estuaries ( $t$ test, $p<0.01$ ), but those from other rivers showed no significant difference $(t$ test, $p>0.05)$. On the other hand, no significant difference ( $t$ test, $p>0.05$ ) in TL was observed among A. marmorata samples. The length-frequency distribution of recruiting A. marmorata and A. japonica glass eels in the Philippines, Taiwan, China, and Japan are shown in Figure 3. Anguilla japonica glass eels at estuarine arrival were significantly longer than $A$. marmorata $(p<0.001)$.
The $T_{\mathrm{t}}$ was observed to be significantly older $(p<0.001)$ in A. japonica (181.8 $\pm 16.2 \mathrm{~d})$ than that in A. marmorata (141.6 \pm 15.8 days), indicating that the latter were recruited to the estuary earlier than the former. On the other hand, the duration of migration from the time of metamorphosis to the time of estuarine arrival $\left(T_{\mathrm{t}-\mathrm{m}}\right)$ was significantly longer in $A$. japonica (41.1 \pm 8.8 days) than that in $A$. marmorata $(28.1 \pm 7.9$ days $)(p<0.001)$. This indicated that after metamorphosing, A. japonica experienced a longer drifting time by coastal currents before being recruited to estuaries than $\operatorname{did} A$. marmorata.

\section{Developmental stages}

The majority of $A$. marmorata collected and examined $(n=168)$ from various estuaries and rivers in East Asia were at stage $\mathrm{V}_{\mathrm{A}}(55.4 \%)$ followed by stage $\mathrm{V}_{\mathrm{B}}$ (44.6\%) (Table 2). No A. marmorata in a more advanced developmental stage (i.e., stages VI or VII) was observed, suggesting that individuals had recently arrived at the river mouth when they were collected. On the other hand, the majority of $A$. japonica examined $(n=240)$ were at stage $\mathrm{V}_{\mathrm{A}}(51.7 \%)$ followed by stages $\mathrm{V}_{\mathrm{B}}(32.1 \%)$, $\mathrm{VI}_{\mathrm{A} 1}(12.5 \%), \mathrm{VI}_{\mathrm{A} 2}(3.3 \%)$, and $\mathrm{VI}_{\mathrm{A} 3}(0.4 \%)$. Also, the occurrence of larger A. japonica individuals in the Yalu

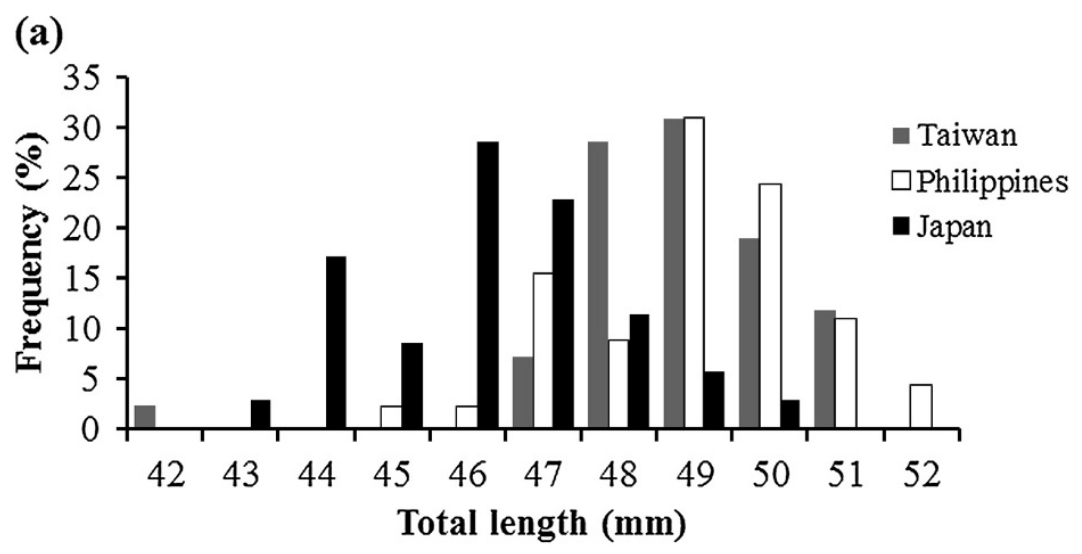

(b)

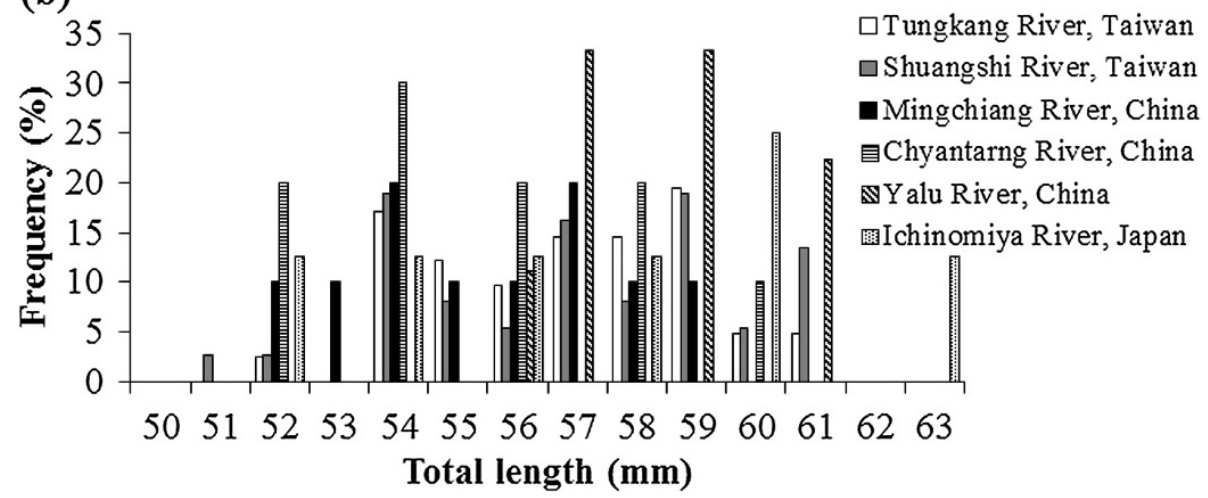

Figure 3 Length-frequency distribution of recruiting Anguilla marmorata (a) and A. japonica (b) glass eels from the Philippines, Taiwan, China, and Japan. 
Table 2 Pigmentation stages of glass eels of Anguilla japonica and Anguilla marmorata collected from various rivers and estuaries in East Asia

\begin{tabular}{|c|c|c|c|c|c|c|c|c|c|}
\hline \multirow[t]{2}{*}{ Species } & \multirow[t]{2}{*}{ Sampling site } & \multirow[t]{2}{*}{ Number } & \multicolumn{7}{|c|}{ Pigmentation stage } \\
\hline & & & $\mathrm{V}_{\mathrm{A}}$ & $\mathrm{V}_{\mathrm{B}}$ & $\mathrm{VI}_{\mathrm{A} 1}$ & $\mathrm{VI}_{\mathrm{A} 2}$ & $\mathrm{VI}_{\mathrm{A} 3}$ & $\mathrm{VI}_{\mathrm{A} 4}$ & $\mathrm{VI}_{\mathrm{B}}$ \\
\hline \multirow[t]{8}{*}{ A. japonica ${ }^{a}$} & Tungkang River, Taiwan & 30 & 28 & 2 & 0 & 0 & 0 & 0 & 0 \\
\hline & & 30 & 24 & 6 & 0 & 0 & 0 & 0 & 0 \\
\hline & Shuangshi River, Taiwan & 30 & 13 & 17 & 0 & 0 & 0 & 0 & 0 \\
\hline & & 30 & 9 & 16 & 5 & 0 & 0 & 0 & 0 \\
\hline & Mingchiang River, China & 30 & 24 & 6 & 0 & 0 & 0 & 0 & 0 \\
\hline & Chyantarng River, China & 30 & 21 & 9 & 0 & 0 & 0 & 0 & 0 \\
\hline & Yalu River, China & 30 & 0 & 1 & 21 & 7 & 1 & 0 & 0 \\
\hline & Ichinomiya River, Japan & 30 & 5 & 20 & 4 & 1 & 0 & 0 & 0 \\
\hline Total & & 240 & 124 & 77 & 30 & 8 & 1 & 0 & 0 \\
\hline$\%$ composition & & & 51.7 & 32.1 & 12.5 & 3.3 & 0.4 & 0 & 0 \\
\hline \multirow[t]{3}{*}{ A. marmorata } & Cagayan River, the Philippines & 45 & 15 & 30 & 0 & 0 & 0 & 0 & 0 \\
\hline & Hsiukuluan River, Taiwan & 86 & 65 & 21 & 0 & 0 & 0 & 0 & 0 \\
\hline & Kurio River, Japan & 37 & 13 & 24 & 0 & 0 & 0 & 0 & 0 \\
\hline Total & & 168 & 93 & 75 & 0 & 0 & 0 & 0 & 0 \\
\hline$\%$ composition & & & 55.4 & 44.6 & 0 & 0 & 0 & 0 & 0 \\
\hline
\end{tabular}

${ }^{\mathrm{a} C h e n g}$ and Tzeng (1996).

River (Table 1) corresponded with their more advanced pigmentation states $\left(\mathrm{VI}_{\mathrm{A} 2}\right.$ and $\left.\mathrm{VI}_{\mathrm{A} 3}\right)$ (Table 2).

\section{Ontogenetic changes in daily growth rate of otoliths}

The overall mean otolith DGI widths of glass eels at different phases of their early life history are shown in Table 3. The mean DGI width before metamorphosis $\left(R_{\mathrm{m}} / T_{\mathrm{m}}\right)$ was $0.8 \pm 0.07 \mu \mathrm{m} /$ days in $A$. japonica and $0.9 \pm 0.14 \mu \mathrm{m} /$ days in $A$. marmorata, which was narrower compared to that of the mean otolith DGI width from the metamorphosis check to the otolith edge $\left(R_{\mathrm{t}-\mathrm{m}}\right)$ which was $1.3 \pm 0.28 \mu \mathrm{m} /$ days in $A$. japonica and $2.1 \pm 0.60 \mu \mathrm{m} /$ days in $A$. marmorata. These results indicated that otolith growth was slower during the leptocephalus stage and faster after metamorphosis in both species. From the primordium to the otolith edge, different otolith growth rates were observed to correspond to different ontogenetic development stages (Figure 2). The first pattern was observed in the region between the primordium and the FFC and was deposited during the yolk-sac stage. In this region, no discernible DGIs were observed, and the $\mathrm{Sr} / \mathrm{Ca}$ ratio was lower because the yolk sac was of freshwater maternal origin (Figure 2). The second pattern was observed in the region between the FFC and MC and was deposited during the leptocephalus stage. Otolith DGIs, on the other hand, became wider beyond the MC. The third pattern was observed in the region between the $\mathrm{MC}$ and otolith edge and was deposited during the glass eel stage. These growth and $\mathrm{Sr} / \mathrm{Ca}$ ratio patterns in otoliths of $A$. marmorata glass eels were similar to those observed in $A$. japonica. This indicated that both species have similar life histories from the spawning ground to the estuary in their early life stage.

Age at metamorphosis in relation to the growth rate and distance from the spawning grounds and to differences in ages between species

The overall mean ( \pm standard deviation) $T_{\mathrm{m}}$ was significantly older in $A$. japonica (140.7 \pm 13.6 days) than that in $A$. marmorata (113.5 \pm 13.0 days) $(p<0.001$, Table 1$)$. It was also found that the $T_{\mathrm{m}}$ increased from south to north in both species (Figure 4). In addition, the $T_{\mathrm{m}}$ was negatively correlated with the growth rate before metamorphosis $\left(G_{\mathrm{m}}\right)$ (Figure 5$)$. On the other hand, $T_{\mathrm{m}}$ values of $A$. marmorata and $A$. japonica were positively related to the larval dispersal distance from the spawning grounds (Figure 6).

\section{Discussion}

The difference in $T_{\mathrm{m}}$ values between $A$. japonica and $A$. marmorata and its biological significance

In the present study, it was found that at an age 110 days (Table 1), A. marmorata had already metamorphosed and commenced migration to coastal waters of the northern Philippines, while $A$. japonica remained at the pelagic leptocephalus stage and continued to drift with currents in the open ocean until it reached 
Table 3 Mean increment widths of radii of $R_{\mathrm{m}}, \boldsymbol{R}_{\mathrm{t}}$, and $\boldsymbol{R}_{\mathrm{t}-\mathrm{m}}$ in otoliths of Anguilla japonica and A. marmorata glass eels

\begin{tabular}{|c|c|c|c|c|c|}
\hline \multirow[t]{2}{*}{ Species } & \multirow[t]{2}{*}{ Sampling site } & \multirow[t]{2}{*}{ Sampling date } & \multicolumn{3}{|c|}{ Increment width in $\mu \mathrm{m}(n)$} \\
\hline & & & $R_{\mathrm{m}}$ & $R_{\mathrm{t}}$ & $R_{\mathrm{t}-\mathrm{m}}$ \\
\hline \multirow[t]{8}{*}{ A. japonica ${ }^{a}$} & Tungkang River, Taiwan & $\begin{array}{c}30 \text { December } \\
92\end{array}$ & $0.8 \pm 0.07(5)$ & $0.9 \pm 0.09$ & $1.2 \pm 0.31(5)$ \\
\hline & & 24 March 93 & $0.8 \pm 0.07(7)$ & $0.8 \pm 0.03(5)$ & $1.4 \pm 0.19(5)$ \\
\hline & Shuangshi River, Taiwan & $\begin{array}{c}20 \text { December } \\
92\end{array}$ & $0.8 \pm 0.07(7)$ & $0.9 \pm 0.03(6)$ & $1.5 \pm 0.48(6)$ \\
\hline & & 17 February 93 & $0.9 \pm 0.09$ & $1.0 \pm 0.04(2)$ & $1.4 \pm 0.03(2)$ \\
\hline & Mingchiang River, China & 1 March 93 & $0.7 \pm 0.02(5)$ & $0.9 \pm 0.06(5)$ & $1.4 \pm 0.38(5)$ \\
\hline & Chyantarng River, China & 17 February 93 & $0.7 \pm 0.08(7)$ & $0.8 \pm 0.03$ & $1.3 \pm 0.17(4)$ \\
\hline & Yalu River, China & 3 May 93 & $0.8 \pm 0.09(8)$ & $0.9 \pm 0.05(8)$ & $1.3 \pm 0.45(8)$ \\
\hline & Ichinomiya River, Japan & 10 January 94 & $0.7 \pm 0.06$ & $0.8 \pm 0.05(5)$ & $1.2 \pm 0.26(5)$ \\
\hline Overall $\left(\mu_{1)}\right.$ & & & $0.78 \pm 0.07(47)$ & $0.88 \pm 0.05(40)$ & $1.34 \pm 0.28(40)$ \\
\hline \multirow[t]{3}{*}{ A. marmorata } & $\begin{array}{c}\text { Cagayan River, the } \\
\text { Philippines }\end{array}$ & 19 May 08 & $1.0 \pm 0.18(13)$ & $1.1 \pm 0.14(13)$ & $1.84 \pm 0.46(13)$ \\
\hline & Hsiukuluan River, Taiwan & 20 May 08 & $0.9 \pm 0.10$ & $1.2 \pm 0.18$ & $2.29 \pm 0.72(13)$ \\
\hline & Kurio River, Japan & 6 June 96 & $0.9 \pm 0.14(15)$ & $1.1 \pm 0.17(15)$ & $2.18 \pm 0.61(15)$ \\
\hline Overall $\left(\mu_{2}\right)$ & & & $0.93 \pm 0.14(41)$ & $1.13 \pm 0.16(41)$ & $2.10 \pm 0.60(41)$ \\
\hline $\begin{array}{l}\text { Difference } \\
\left(\mu_{2-} \mu_{1)}\right.\end{array}$ & & & 0.15 & 0.25 & 0.76 \\
\hline Significance & & & $\begin{array}{c}\text { A. marmorata }>A . \\
\text { japonica }\end{array}$ & $\begin{array}{c}\text { A. marmorata } \\
\text { japonica }\end{array}$ & $\begin{array}{c}\text { A. marmorata } \\
\text { japonica }\end{array}$ \\
\hline
\end{tabular}

${ }^{a}$ Cheng and Tzeng (1996). Mean increment widths ( $( \pm \mathrm{SD})$ of radii of $R_{\mathrm{m}}, R_{\mathrm{t}}$, and $R_{\mathrm{t}-\mathrm{m}}$ in otoliths of $A$. japonica and A. marmorata glass eels. $n$, number of individuals used for increment width measurements.

northern Taiwan where it began to metamorphose approximately 24 days later. This must be the reason why the geographic distribution of $A$. japonica is more northerly than that of $A$. marmorata. The metamorphosis of leptocephalus to glass eels transforms the laterally compressed, willow leaf-like shape of the former to a more rounded, streamlined shape of the latter. This transformation reportedly causes drastic reductions in the length and weight of the leptocephalus and an estimated $80 \%$ drop in whole body water (Bertin 1951; Otake 2003). Previous studies found that the body shape of the leptocephalus is suitable for drifting with oceanic currents (Miller 2009; Tsukamoto et al. 2009; Tsukamoto et al. 2011). Also, the laterally compressed willow leaf-like body shape of the anguillid leptocephalus and the high body water content greatly contribute to its buoyancy and is favorable for passive planktonic drift and transport by ocean currents, while the body of the glass eel is more adapted for bottom dwelling. Once the leptocephalus metamorphose into a glass eel, it loses buoyancy and leaves the strong ocean currents. In other words, metamorphosis from a leptocephalus to a glass eel in anguillid species terminates the passive drift of eel larvae and initiates migration to coastal waters, and it also determines the ultimate destination of larval dispersal. The completion of eel larval metamorphosis and the onset of the juvenile stage initiate a behavioral shift from pelagic migration to bottom settlement (Moran 1994). Earlier metamorphosing leptocephali are recruited earlier, while delayed metamorphosis leptocephali are bound for longer oceanic dispersal and later estuarine recruitment. Metamorphosis occurs during migration from their offshore marine spawning grounds to their continental freshwater growth habitats, and it marks an adaptive shift from oceanic drifting to river colonization and the beginning of the continental dispersal phase (Edeline et al. 2009). DGIs in otoliths can conveniently provide the timing for metamorphosis $\left(T_{\mathrm{m}}\right)$, and the radius from the $\mathrm{P}$ to the $\mathrm{MC}$ can provide information on the 'metamorphosing size' of anguillid eels. These allowed us to gain insights into the mechanism of metamorphosis of anguillid eels in the wild and provided clues to understanding the biological significance of differences in the $T_{\mathrm{m}}$, size at metamorphosis, and in growth rate of leptocephali between A. japonica and A. marmorata. Tsukamoto (1990) suggested that $A$. japonica begins to metamorphose when leptocephali reach $60 \mathrm{~mm} \mathrm{TL}$. On the other hand, metamorphosis of leptocephali of $A$. marmorata and other tropical eel species like Anguilla bicolor pacifica, Anguilla borneensis, and Anguilla celebesensis was found to commence at around $50 \mathrm{~mm}$ TL (Kuroki et al. 2005, 2006), which is considerably smaller than the metamorphosing size of the temperate A. japonica. 


\section{A. japonica}

(a1)

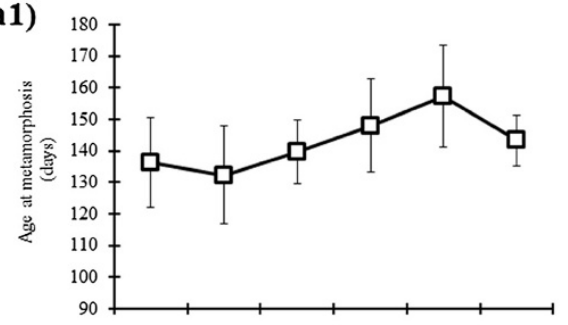

(b1)

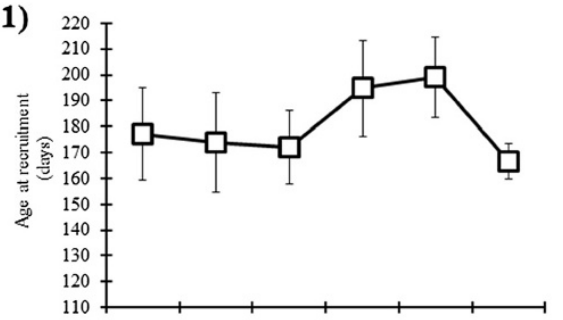

(c1)

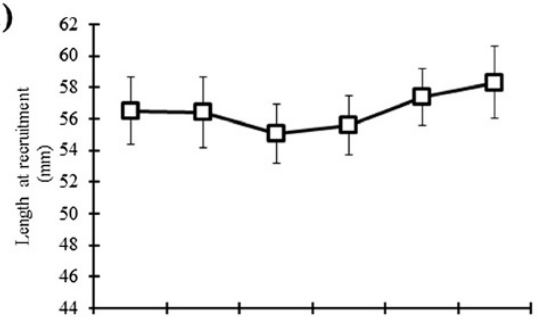

(d1)

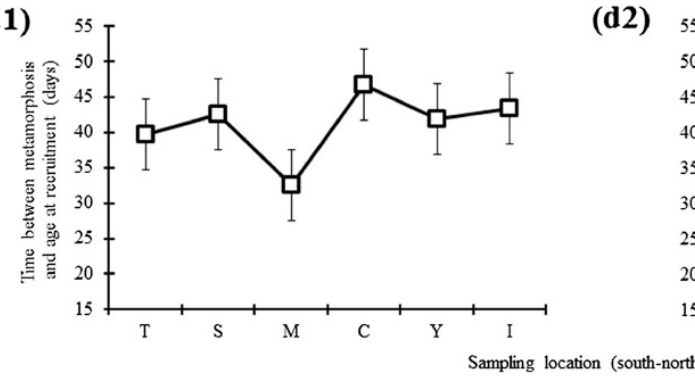

(a2)

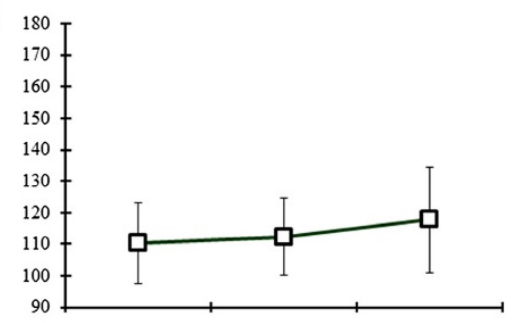

(b1)

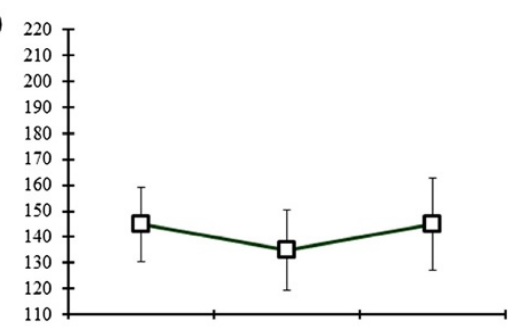

(c2)
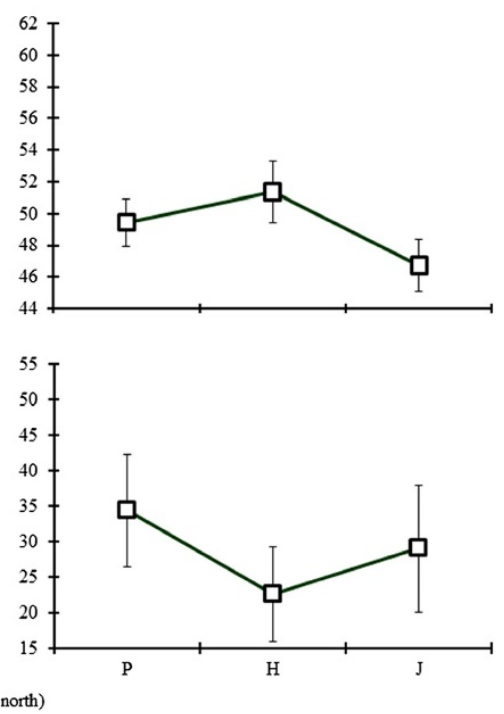

Figure 4 Spatial changes of Anguilla japonica and A. marmorata. Spatial changes in age at metamorphosis $\left(\mathbf{a}_{1}\right.$ to $\left.\mathbf{a}_{\mathbf{2}}\right)$, age $\left(\mathbf{b}_{\mathbf{1}}\right.$ to $\left.\mathbf{b}_{2}\right)$, and length $\left(\mathbf{c}_{\mathbf{1}}\right.$ to $\left.\mathbf{c}_{\mathbf{2}}\right)$ at recruitment, and time between metamorphosis and age at recruitment $\left(\mathbf{d}_{\mathbf{1}}\right.$ to $\left.\mathbf{d}_{\mathbf{2}}\right)$ of Anguilla japonica and A. marmorata. Abbreviations of sampling locations are given in Figure 1.

Differences in the timing and duration of metamorphosis between $A$. japonica and $A$. marmorata

Previous studies indicated that the timing and duration of metamorphosis from leptocephali to glass eels differed between temperate and tropical anguillid eels around the world, with a tendency for tropical species like $A$. marmorata to begin metamorphosis at a much younger age and complete it in a shorter time than temperate species (Chang and Tzeng 1996; Wang and Tzeng 1998, 2000; Arai et al. 1999a; Shiao et al. 2001). In this study, we found that the temperate eel $A$. japonica exhibited older metamorphosis timing and experienced a longer leptocephalus stage than the tropical $A$. marmorata. Arai et al. (2001b) noted that this tendency was brought about by differences in the temperature experienced by leptocephali of temperate and tropical eels during their migration to coastal waters from their spawning areas. However, this might not be true for A. japonica and A. marmorata since they begin migration from the same general spawning area (Kuroki et al. 2009) and drift with the same current system (NEC and $\mathrm{KC}$ ). In addition, $A$. rostrata and $A$. anguilla also experience similar temperature and current systems during their inshore migration from their spawning grounds, but their ages at metamorphosis differ from each other (Wang and Tzeng 1998). These facts suggest that genetic modifications and evolutionary strategies (e.g., low growth rate/metabolism during the larval stage and a long larval duration) 


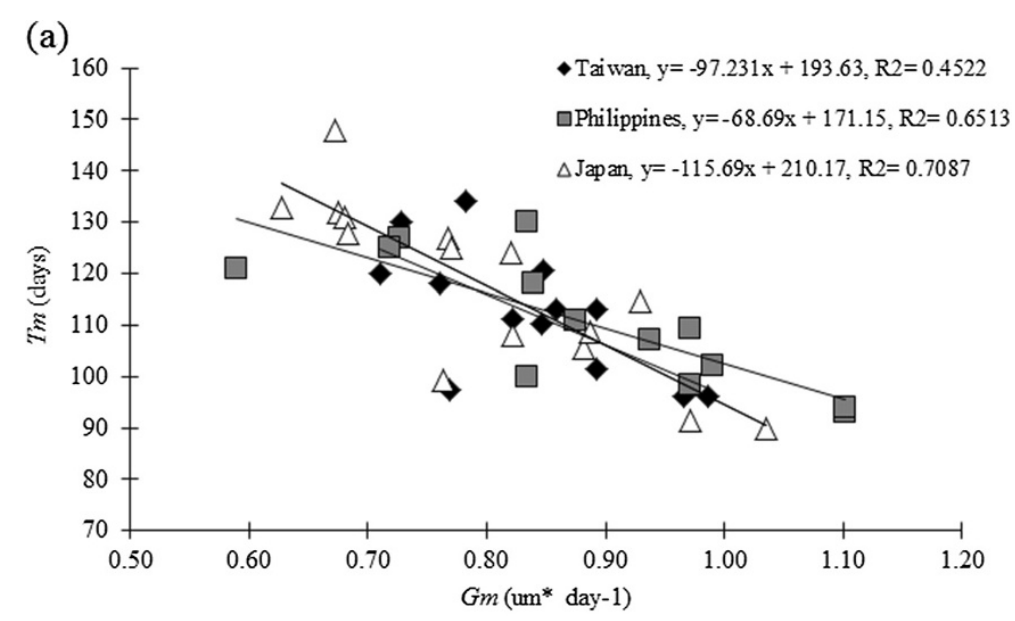

(b)

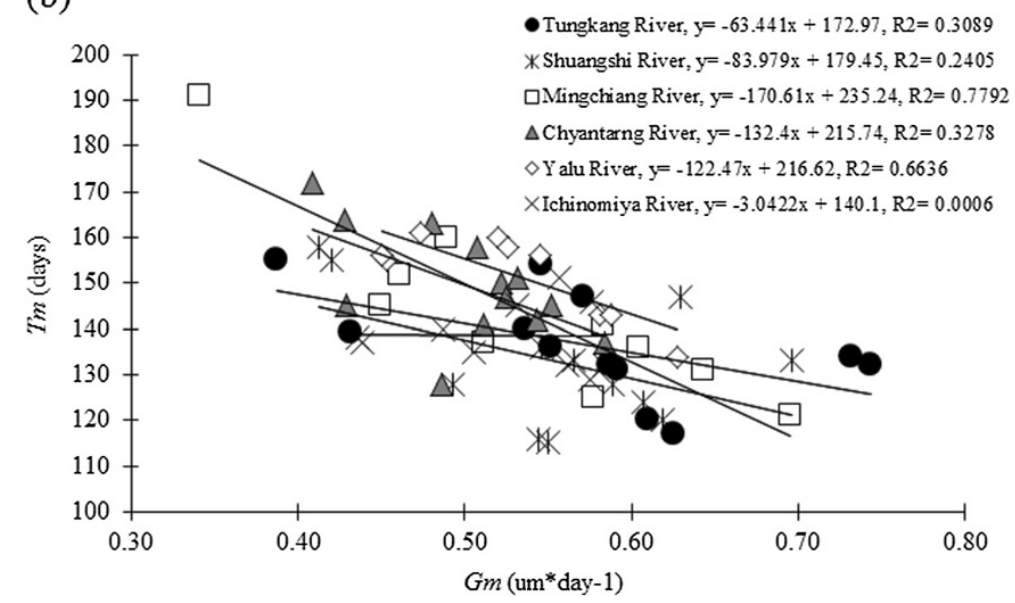

Figure 5 Relationship between the age at metamorphosis and growth rate before metamorphosis. Relationship between the age at metamorphosis $\left(T_{\mathrm{m}}\right)$ and growth rate $\left(G_{\mathrm{m}}\right)$ before metamorphosis in Anguilla marmorata (a) and A. japonica (b).

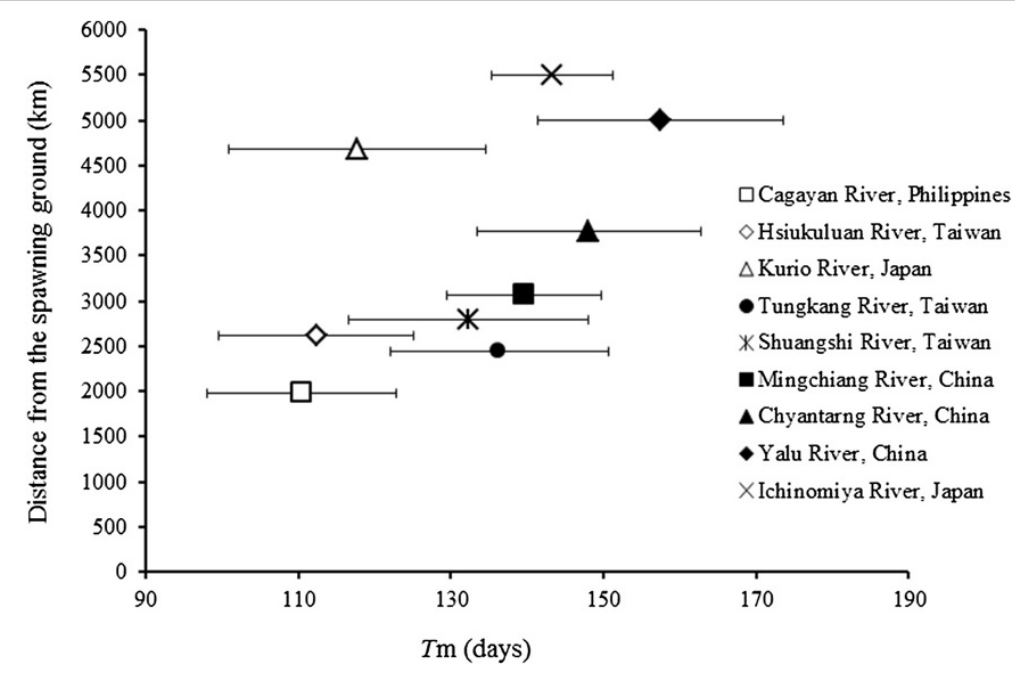

Figure 6 Relationship between the larval dispersal distance and age at metamorphosis. Relationship between the larval dispersal distance and age at metamorphosis ( $\left.T_{m}\right)$ in Anguilla marmorata (open symbols) and A. japonica (solid symbols). 
of eel species are more important than the influence of temperature on differences in the timing and duration of metamorphosis between $A$. japonica and A. marmorata.

\section{Delayed metamorphosis as a means of long-distance dispersal of the eel}

At the end of their long transoceanic migration, $A$. japonica and $A$. marmorata leptocephali metamorphose into glass eels and invade coastal and inland habitats. Otolith microchemical studies revealed that after reaching coastal waters, glass eels may either migrate further inland and colonize freshwater habitats or stop their upstream migration and settle in seawater or estuaries (Tzeng et al. 2002; Arai et al. 2004; Daverat et al. 2006). The timing of metamorphosis by a leptocephalus into a glass eel and transport by oceanic currents are considered key determinants of the ultimate destination of eels (Cheng and Tzeng 1996; Tzeng 2003). In the present study, we found that the age of A. marmorata at metamorphosis from leptocephalus to glass eel $(113.5 \pm 13.0$ days) was younger than in A. japonica (140.7 \pm 13.6 days). Because metamorphosis triggers a behavioral switch from pelagic migration to bottom settlement, $A$. japonica leptocephali which arrive in Philippine waters are apparently too young to metamorphose and migrate towards estuaries so they continue drifting northwards or southwards. This must be the reason why Japanese eels are seldom found in the Philippines, while $A$. marmorata occurs in abundance (Tabeta et al. 1975, 1976). A similar scenario was also observed in American and European eels, for which differences in the duration of the leptocephalus stage and growth rates were the principal factors triggering segregative migration of these two species in the Atlantic Ocean (Wang and Tzeng 2000). The delay in metamorphosis of about 12 to 15 months in A. anguilla (McCleave 1993; Wang and Tzeng 2000) is necessary for its long-distance dispersal that includes a trans-Atlantic crossing. Similarly, it seems that A. japonica has developed a strategy to delay its metamorphosis from leptocephali to glass eels by reducing its growth rate, which enables it to migrate segregatively with A. marmorata and experience long-distance dispersal in East Asia. Its faster growing and earlier metamorphosing leptocephali are recruited in Taiwan, while those that do not continue to drift towards eastern China and Japan. On the other hand, the faster growing and earlier metamorphosing leptocephali of $A$. marmorata are recruited earlier in the Philippines, while its slower growing, delayed metamorphosing leptocephali disperse southward (via the Mindanao Current) and northward (via the $\mathrm{KC}$ ). The difference in age at metamorphosis between A. japonica and A. marmorata ranged 18.5 to 39.9 days, and the delay in metamorphosis of 18.5 to 39.9 days is enough to allow $A$. japonica to be transported from North Luzon, the Philippines to further north in continental East Asia by the $\mathrm{KC}$. Aside from these considerations, anomalies in the hydrology of the region should also be taken into account because they might also influence the duration of larval drift and subsequently delay metamorphosis and affect recruitment. Anomalies such as El Niño and El Niño Southern Oscillation were found to affect current systems in the region. During El Niño years, the salinity front in the NEC region retreats southward, leading to a southward shift in the spawning grounds, causing poor recruitment (Kimura et al. 2001; Sugimoto et al. 2001; Kim et al. 2007; Han et al. 2009b). During this period, leptocephali experience longer drift, slower growth rates, delayed metamorphosis, and ultimately delayed recruitment. But during non-El Niño years, the hydrology of the region changes with the season, and these changes are more or less regular. Specimens examined in the present study were collected from different years during their peak recruitment seasons during non-El Niño years. Accordingly, the effects of environmental factors, such as El Niño events, on larval transportation and subsequently delayed metamorphosis from leptocephali to glass eels were not examined in this study and would be a good topic for future research and long-term studies.

\section{Early growth of Anguilla leptocephali}

The migratory segregation between A. japonica and A. marmorata in the northwestern Pacific can be further understood by examining their larval growth rates. Patterns of ontogenetic changes in otolith DGIs from the $\mathrm{P}$ to the otolith edge were found to be similar between A. japonica (Cheng and Tzeng 1996; Tzeng 2003) and A. marmorata (Table 1, Figure 2); however, otolith DGI widths were greater and increment numbers were fewer in A. marmorata than A. japonica (Tables 1 and 3). This indicates that during the early stage of development, A. marmorata has faster otolith growth rates than $A$. japonica. Faster growing leptocephali are able to metamorphose and are recruited earlier to estuaries in the Philippines, while slower growing ones metamorphose and are recruited later to estuaries in Taiwan, eastern China, Korea, and Japan. In addition to this, a close linear relationship between ages at metamorphosis and recruitment in temperate and tropical eel species was observed (Marui et al. 2001), further suggesting that early-metamorphosing glass eels are recruited at younger ages. A similar phenomenon was also observed in other anguillid species like A. celebesensis, Anguilla bicolor bicolor, A. bicolor pacifica, A. australis, A. anguilla, A. rostrata, and Anguilla dieffenbachi. A reduced growth rate in $A$. japonica larvae prevents metamorphosis in synchrony with $A$. marmorata despite their overlapping spawning sites and the same oceanic transport and 
migratory routes. Also, the slower growth rate of $A$. japonica during the leptocephalus stage and its longer duration compared to A. marmorata seem to be due to the longer transportation distance.

\section{Conclusions}

In conclusion, the larval growth rate and metamorphosis timing $\left(T_{\mathrm{m}}\right)$ may play important roles in the geographical distribution of the sympatric anguillid eel species A. japonica and A. marmorata in the northwestern Pacific during their drift from their overlapping spawning grounds in waters west of the Mariana Islands via the NEC and $\mathrm{KC}$ to their continental freshwater growth habitats. A. marmorata grows faster and metamorphoses earlier than A. japonica; thus, it can be abundantly found in the tropical Philippines and subtropical Taiwan, but few are seen in temperate China, Korea, and Japan. On the contrary, the temperate eel A. japonica is abundant beyond Taiwan, and few or none are found in the tropical Philippines. This indicates that differences in growth rates and the timing of metamorphosis from leptocephali to glass eels are key factors determining the continental distribution of these two sympatric anguillid eel species. Delayed metamorphosis with a reduced growth rate in A. japonica leptocephali may be an evolutionary strategy for temperate species to extend their distribution area from a tropical to a temperate region, farther north than the distribution range of $A$. marmorata.

\section{Competing interests}

The authors declare that they have no competing interests.

\section{Authors' contributions}

NJL participated in the design of the study, carried out otolith analyses, analyzed and interpreted the data and drafted the manuscript. WNT conceived the study and participated in its design and coordination and in the interpretation of data. KNS participated in otolith analyses and interpretation of data. NTY participated in otolith analyses. YSH provided technical and material support and participated in the interpretation and analyses of data. All authors read and approved the final manuscript.

\section{Acknowledgments \\ This study was financially supported by the National Science Council of Taiwan (awarded to WNT). The authors are grateful to the students of the Fisheries Biology Laboratory, Institute of Fisheries Science, National Taiwan University (Taipei, Taiwan) for their assistance; to Dr. RT Chen and the staff of the Endemic Species Research Institute, Nantou, Taiwan; Dr. AV Yambot, Central Luzon State University, Muñoz, the Philippines; and Dr. N Mochioka, Kyushu University, Fukuoka, Japan for providing eel specimens; to Dr. Y lizuka, Academia Sinica, Taipei, Taiwan for measuring the otolith microchemistry; and to the anonymous reviewers for providing valuable suggestions on the manuscript.}

Received: 29 March 2013 Accepted: 3 July 2013

Published: 4 October 2013

\section{References}

Amiard-Triquet C, Amiard JC, Andersen AC, Elie P, Metayer C (1988) The eel (Anguilla anguilla) as a bioindicator of metal pollution: factor limiting its use. Water Sci Technol 19:1229-1232
Arai T, Otake T, Tsukamoto K (1997) Drastic changes in otolith microstructure and microchemistry accompanying the onset of metamorphosis in Japanese eel Anguilla japonica. Mar Ecol Progr Ser 161:17-22

Arai T, Limbong D, Otake T, Tsukamoto K (1999a) Metamorphosis timing and inshore migration of tropical eels, Anguilla spp., in the Indo-Pacific. Mar Ecol Progr Ser 182:283-293

Arai T, Otake T, Jellyman DJ, Tsukamoto K (1999b) Differences in the early life history of the Australian shortfinned eel Anguilla australis from Australia and New Zealand, as revealed by otolith microstructure and microchemistry. Mar Biol 135:381-389

Arai T, Otake T, Limbong D, Tsukamoto K (1999c) Early life history and recruitment of the tropical eel, Anguilla bicolor pacifica, as revealed by otolith microstructure and microchemistry. Mar Biol 133:319-326

Arai T, Limbong D, Tsukamoto K (2000) Validation of otolith daily growth increments in the tropical eel Anguilla celebesensis. Can J Zool 78:1078-1084

Arai T, Aoyama J, Ishikawa S, Miller MJ, Otake T, Inagaki T, Tsukamoto K (2001a) Early life history of tropical Anguilla leptocephali in the western Pacific Ocean. Mar Biol 138:887-895

Arai T, Limbong D, Otake T, Tsukamoto K (2001 b) Recruitment mechanisms of tropical eels Anguilla spp. and implications for the evolution of oceanic migration in the genus Anguilla. Mar Ecol Progr Ser 216:253-264

Arai T, Marui M, Miller MJ, Tsukamoto K (2002a) Growth history and inshore migration of the tropical eel, Anguilla marmorata, in the Pacific. Mar Biol 140:309-316

Arai T, Marui M, Otake T, Tsukamoto K (2002b) Coastal migration of tropical eel, Anguilla marmorata, from Taiwanese and Japanese coasts. Fish Sci 68:152-157

Arai T, Kotake A, Lokinan PM, Miller MJ, Tsukamoto K (2004) Evidence of different habitat use by New Zealand freshwater eels Anguilla australis and $A$. dieffenbachi as revealed by otolith microchemistry. Mar Ecol Progr Ser 266:213-225

August SM, Hicks BJ (2008) Water temperature and upstream migration of glass eels in New Zealand: implications of climate change. Environ Biol Fish 81:195-205

Bertin L (1951) Les anguilles. Payot, Paris

Bertin L (1956) Eels-a biological study. Cleaver-Hume Press, London

Bonhommeau S, Chassot E, Planque B, Knap A, Le Pape O (2008) Impact of climate on eel populations of Northern Hemisphere. Mar Ecol Progr Ser 373:71-80

Briand C, Fatin D, Fontenelle G, Feunteun E (2003) Estuarine and fluvial recruitment of the European glass eel Anguilla anguilla in an exploited estuary. Fish Manage Ecol 10:377-384

Busch WDN, Lary SJ, Castilione CM, McDonald RP (1998) Distribution and availability of Atlantic coast freshwater habitats for American eel (Anguilla rostrata). US Fish and Wildlife Service, Administrative report, Amherst, New York, pp 98-92

Casselman JM (2002) Effects of temperature, global extremes and climate change on year-class production of warmwater, coolwater and coldwater fishes in the Great Lakes Basin. In: McGinn NA (ed) Proceedings of American Fisheries Society Symposium 32. American Fisheries Society, Bethesda, p 39

Castonguay M, Hodson PV, Moriarty C, Drinkwater KF, Jessop B (1994) Is there a role of ocean environment in American and European eel decline? Fish Oceanogr 3:197-203

Cheng PW, Tzeng WN (1996) Timing of metamorphosis and estuarine arrival across the dispersal range of the Japanese eel Anguilla japonica. Mar Ecol Progr Ser 131:87-96

Chisnall BL, Martin ML, Hicks BJ (2003) Effect of harvest on size, abundance and production of freshwater eels (Anguilla australis and A. dieffenbachii) in a New Zealand stream. In: Dixon DA (ed) Biology, management and protection of catadromous eels. American Fisheries Society, Bethesda, pp 177-189

Cieri MD, McCleave JD (2001) Validation of daily otolith increments in glass-phase American eels Anguilla rostrata during estuarine residency. J Exp Mar Biol Ecol 257:219-227

Clevestam PD, Ogonowski M, Sjoberg NB, Wickstrom H (2011) Too short to spawn? Implications of small body size and swimming distance on successful migration and maturation of the European eel Anguilla anguilla. J Fish Biol 78:1073-1089

Daverat F, Limburg KE, Thibault I, Shiao JC, Dodson JJ, Caron F, Tzeng WN, lizuka Y, Wickstrom H (2006) Phenotypic plasticity of habitat use by three temperate eel species Anguilla anguilla, A. japonica and A. rostrata. Mar Ecol Progr Ser 308:231-241

Dekker W (2003) Did lack of spawners cause the collapse of the European eel, Anguilla anguilla? Fish Manage Ecol 10:365-376 
Dekker W (2008) Coming to grips with the eel stock slip-sliding away. In: Schechter MG, Leonard NJ (eds) International governance of fisheries ecosystems: learning from the past, finding solutions for the future. American Fisheries Society, Bethesda, pp 335-355

Edeline E, Dufour S, Elie P (2009) Proximate and ultimate control of eel continental dispersal. In: van den Thillart G, Dufour S, Cliff Rankin J (eds) Spawning migration of the European eel. Springer, London, pp 433-461

Friedland KD, Miller MJ, Knights B (2007) Oceanic changes in the Sargasso Sea and declines in the recruitment of European eel. ICES J Mar Sci 64:519-530

Fukuda N (2010) Inshore and upstream migration of Japanese eels in the Hamana Lake System, PhD thesis. University of Tokyo, Japan

Graynoth E, Jellyman D, Bonnett M (2008) Spawning escapement of female longfin eels. Ministry of Fisheries, New Zealand Fisheries Assessment Report 2008/7, Wellington

Haenen O, van Ginneken V, Engelsma M, van den Thillart G (2002) Impact of eel viruses on recruitment of European eel. In: van den Thillart G, Dufour S, Cliff Rankin J (eds) Spawning migration of the European eel. Springer, London, pp 387-400

Han YS, Tzeng WN (2006) Use of the sex ratio as a means of resource assessment for the Japanese eel Anguilla japonica: a case study in the Kaoping River, Taiwan. Zool Stud 45:255-263

Han YS, Chang YT, Taraschewski H, Chang SL, Chen CC, Tzeng WN (2008) The swimbladder parasite Anguillicola crassus in native Japanese eels and exotic American eels in Taiwan. Zool Stud 47:667-675

Han YS, Chang YT, Tzeng WN (2009a) Variable habitat use by Japanese eel affects dissemination of swimbladder parasite Anguillicola crassus. Aquat Biol 5:143-147

Han YS, Tzeng WN, Liao IC (2009b) Time series analysis of Taiwanese catch data of Japanese glass eels Anguilla japonica: possible effects of the reproductive cycle and El Niño events. Zool Stud 48:632-639

Han YS, Yambot AV, Zhang H, Hung CL (2012) Sympatric spawning but allopatric distribution of Anguilla japonica and Anguilla marmorata: temperature- and oceanic current-dependent sieving. Plos ONE 7:e37484

Haro A, Richkus W, Whalen K, Hoar A, Busch W-D, Lary S, Brush T, Dixon D (2000) Populations decline of the American eel: implications for future research and management. Fish 25:7-16

Hoyle SD, Jellyman DJ (2002) Longfin eels need reserves: modeling the effects of commercial harvest on stocks of New Zealand eels. Mar Freshw Res 53:887-895

Ishikawa S (1998) Molecular study on the population structure of Anguilla marmorata, PhD thesis. University of Tokyo

Ishikawa S, Tsukamoto K, Nishida M (2004) Genetic evidence for multiple geographic populations of the giant mottled eel Anguilla marmorata in the Pacific and Indian oceans. Ichthyol Res 51:343-353

Jansen HM, Winter HV, Bruijs MC, Polman HJG (2007) Just go with the flow? Route selection and mortality during downstream migration of silver eels in relation to river discharge. ICES J Mar Sci 64:1437-1443

Jellyman DJ, Graynoth E, Francis RICC, Chisnall BL, Beentjes MP (2000) A review of the evidence for a decline in the abundance of longfinned eels (Anguilla dieffenbachi) in New Zealand. Ministry of Fisheries Research Project EEL9802, Final Research Report, Auckland

Kim H, Kimura S, Shinoda A, Kitagawa T, Sasai Y, Sasaki H (2007) Effect of El Niño on migration and larval transport of the Japanese eel (Anguilla japonica). ICES J Mar Sci 64:1387-1395

Kimura S, Inoue T, Sugimoto T (2001) Fluctuation in the distribution of lowsalinity water in the North Equatorial Current and its effect on the larval transport of the Japanese eel. Fish Oceanogr 10:51-60

Kirk RS (2003) The impact of Anguillicola crassus on European eels. Fish Manage Ecol 10:385-394

Knights B (2003) A review of the possible impacts of long-term oceanic and climate changes and fishing mortality on recruitment of anguillid eels of the Northern Hemisphere. Sci Total Environ 310:237-244

Kuroki M, Aoyama J, Miller MJ, Arai T, Sugeha HY, Minagawa G, Wouthuyzen S, Tsukamoto K (2005) Correspondence between otolith microstructural changes and early life history events in Anguilla marmorata leptocephali and glass eels. Coast Mar Sci 29:154-161

Kuroki M, Aoyama J, Miller MJ, Wouthuyzen S, Arai T, Tsukamoto K (2006) Contrasting patterns of growth and migration of tropical anguillid leptocephali in the Western Pacific and Indonesian Seas. Mar Ecol Progr Ser 309:233-246

Kuroki M, Aoyama J, Miller MJ, Yoshinaga T, Shinoda A, Hagihara S, Tsukamoto K (2009) Sympatric spawning of Anguilla marmorata and Anguilla japonica in the western North Pacific Ocean. J Fish Biol 74:1853-1865
Leander NJ, Shen KN, Chen RT, Tzeng WN (2012) Species composition and seasonal occurrence of recruiting glass eels (Anguilla spp.) in Hsiukuluan River, eastern Taiwan. Zool Stud 51:59-71

Lin YJ, Chang YJ, Sun CL, Tzeng WN (2010) Evaluation of the Japanese eel fishery in the lower reaches of the Kao-Ping River, southwestern Taiwan using a per-recruit analysis. Fish Res 106:329-336

Lukas R, Firing E, Hacker P, Richardson PL, Collins CA, Fine R, Gammon R (1991) Observations of the Mindanao Current during the Western Equatorial Pacific Ocean circulation study. J Geophys Res 96:7089-7104

Martin MH (1995) Validation of daily growth increments in otoliths of Anguilla rostrata (Le Sueur) elvers. Can J Zool 73:208-211

Marui M, Arai T, Miller MJ, Jellyman DJ, Tsukamoto K (2001) Comparison of early life history between New Zealand temperate eels and Pacific tropical eels revealed by otolith microstructure and microchemistry. Mar Ecol Progr Ser 213:273-284

McCleave JD (1993) Physical and behavioral controls on the oceanic distribution and migration of leptocephali. J Fish Biol 42:243-273

McCleave JD (2001) Simulation of the impact of dams and fishing weirs on reproductive potential of silver-phase American eels in the Kennebec River Basin, Maine. North Am J Fish Manage 21:592-605

McCleave JD, Jellyman DJ (2004) Male dominance in the New Zealand longfin eel population of a New Zealand river: probable causes and implications for management. North Am J Fish Manage 24:490-505

Miller MJ (2009) Ecology of anguilliform leptocephali; remarkable transparent fish larvae of the ocean surface layer. Aqua-BioSci Monogr 2:1-94

Miller MJ, Mochioka N, Otake T, Tsukamoto K (2002) Evidence of a spawning area of Anguilla marmorata in the western North Pacific. Mar Biol 140:809-814

Miller MJ, Kimura S, Friedland KD, Knights B, Kim H, Jellyman DJ, Tsukamoto K (2009) Review of ocean-atmospheric factors in the Atlantic and Pacific Oceans influencing spawning and recruitment of anguillid eels. Am Fish Soc Symp 69:231-249

Minegishi Y, Aoyama J, Tsukamoto K (2008) Multiple population structure of the giant mottled eel, Anguilla marmorata. Mol Ecol 17:3109-3122

Moran RA (1994) Adaptation and constraint in the complex life cycles of animals. Annu Rev Ecol Syst 25:573-600

Moriarty C, Dekker W (1997) Management of the European eel Anguilla anguilla. Fish Bull 15:1-110

Nitani H (1972) Beginning of the Kuroshio. In: Stommel H, Yashida K (eds) Kuroshio: Its physical aspects. University of Tokyo Press, pp 129-163

Otake T (2003) Metamorphosis. In: Aida K, Tsukamoto K, Yamauchi K (eds) Eel biology. Springer, Tokyo, pp 61-74

Otake T, Ishii T, Nakahara M, Nakamura R (1994) Drastic changes in otolith strontium/calcium ratios in leptocephali and glass eels of Japanese eel Anguilla japonica. Mar Ecol Progr Ser 112:189-193

Otake T, Ishii T, Nakahara M, Nakamura R (1997) Changes in otolith strontium:calcium ratios in metamorphosing Conger myriaster leptocephali. Mar Biol 128:565-572

Palstra AP, Heppener DFM, van Ginneken VJT, Szekely C, van den Thillart G (2006) Are dioxin-like contaminants responsible for the eel (Anguilla anguilla) drama? Naturwissenschaften 93:145-148

Parker D, Weyl OLF, Tarachewski H (2011) Invasion of a South African Anguilla mossambica (Anguillidae) population by the alien gill worm Pseudodactylogyrus anguillae (Monogenea). Afr Zool 46:371-377

Richkus WA, Whalen K (2000) Evidence for a decline in the abundance of the American eel, Anguilla rostrata (LeSueur), in North America since the early 1980s. Dana 12:83-97

Robinet T, Feunteun E (2002) Sublethal effects of exposure to chemical compounds: a cause for the decline in Atlantic eels? Ecotoxicol 11:265-277

Sasal P, Tarachewski H, Valade P, Grondin H, Wielgoss S, Moravec F (2008) Parasite communities in the eels of the island of Reunion (Indian Ocean): a lesson in parasite introduction. Parasitol Res 102:1343-1350

Shiao JC, Tzeng WN, Collins A, Jellyman DJ (2001) Dispersal pattern of glass eel stage of Anguilla australis revealed by otolith growth increments. Mar Ecol Progr Ser 219:241-250

Shiao JC, lizuka Y, Chang CW, Tzeng WN (2003) Disparities in habitat use and migratory behavior between tropical eel Anguilla marmorata and temperate eel A. japonica in four Taiwanese rivers. Mar Ecol Progr Ser 261:233-242

Strubberg AC (1913) The metamorphosis of elver as influenced by outward conditions, Meddelelser fra Kommissionen for Havunderseger Series Fiskeri. Copenhagen, pp 4-11

Sugeha HY, Arai T, Miller MJ, Limbong D, Tsukamoto K (2001a) Coastal migration of the tropical eels Anguilla spp. recruiting to the Poigar River estuary on north Sulawesi Island. Mar Ecol Progr Ser 221:233-243 
Sugeha HY, Shinoda A, Marui M, Arai T, Tsukamoto K (2001b) Validation of otolith daily increments in the tropical eel Anguilla marmorata. Mar Ecol Progr Ser 220:291-294

Sugimoto T, Kimira S, Tadokoro K (2001) Impact of El Niño events and climate regime shift on living resources in the western North Pacific. Progr Oceanogr 49:113-127

Sures B, Knopf K (2004) Parasites as a threat to freshwater eels? Sci 304:209-211

Szekely C, Palstra A, Molnar K, van den Thillart G (2002) Impact of the swimbladder parasite on the health and performance of European eels. In: van den Thillart G, Dufour S, Cliff Rankin J (eds) Spawning migration of the European eel. Springer, London, pp 201-226

Tabeta O, Mochioka N (2003) The glass eel. In: Aida K, Tsukamoto K, Yamauchi K (eds) Eel biology. Springer, Tokyo, pp 75-87

Tabeta O, Takai T, Matsui I (1975) Record of the Japanese eel from the Philippines. Bull Jpn Soc Sci Fish 41:641-644

Tabeta O, Tanimoto T, Takai T, Matsui I, Inamura T (1976) Seasonal occurrence of anguillid elvers in Cagayan River, Luzon Islands, the Philippines. Bull Jpn Soc Sci Fish 42:421-426

Tabeta O, Tanaka K, Yamada J, Tzeng WN (1987) Aspects of the early life history of the Japanese eel Anguilla japonica determined from otolith microstructure. Bull Jpn Soc Sci Fish 53:1727-1734

Tanaka H, Kagawa H, Ohta H, Okuzawa K, Hirose K (1995) The first report of eel larvae ingesting rotifers. Fish Sci 61:171-172

Tatsukawa K (2003) Eel resources in East Asia. In: Aida K, Tsukamoto K, Yamauchi K (eds) Eel biology. Springer, Tokyo, pp 293-300

Tesch FW (1977) The eel: biology and management of anguillid eels. Chapman and Hall, London

Tesch FW (2003) The eel, 3rd edn. Blackwell, Oxford

Tsukamoto K (1990) Recruitment mechanism of the eel, Anguilla japonica, to the Japanese coast. J Fish Biol 36:659-671

Tsukamoto K, Yamada Y, Okamura A, Kaneko T, Tanaka H, Miller MJ, Horie N, Mikawa N, Utoh T, Tanaka S (2009) Positive buoyancy in eel leptocephali: an adaptation for life in the ocean surface layer. Mar Biol 156:835-846

Tsukamoto K, Chow S, Otake T, Kurogi H, Mochioka N, Miller MJ, Aoyama J, Kimura S, Watanabe S, Yoshinaga T, Shinoda A, Kuroki M, Oya M, Watanabe T, Hata K, ljiri S, Kazeto Y, Nomura K, Tanaka H (2011) Oceanic spawning ecology of freshwater eels in the western North Pacific. Nat Commun 2:179

Tzeng WN (1982) New record of the elver, Anguilla celebesensis Kaup, from Taiwan. Chin Biosci 19:57-66 (in Chinese with English abstract)

Tzeng WN (1990) Relationship between growth rate and age at recruitment of Anguilla japonica elvers in a Taiwan estuary as inferred from otolith growth increments. Mar Biol 107:75-81

Tzeng WN (1995) Migratory history recorded in otoliths of the Japanese eel, Anguilla japonica, elvers as revealed from SEM and WDS analysis. Zool Stud Supplement 1:234-236

Tzeng WN (1996) Effects of salinity and ontogenetic movements on strontium: calcium ratios in the otoliths of the Japanese eel, Anguilla japonica Temminck and Schlegel. J Exp Mar Biol Ecol 199:111-122

Tzeng WN (2003) The processes of inshore migration of the Japanese eel Anguilla japonica as revealed by otolith microstructure. In: Aida K, Tsukamoto K, Yamauchi K (eds) Eel biology. Springer, Tokyo, pp 181-190

Tzeng WN, Tabeta O (1983) First record of the short-finned eel, Anguilla bicolor pacifica, elvers from Taiwan. Bull Jpn Soc Sci Fish 49:27-32

Tzeng WN, Tsai YC (1992) Otolith microstructure and daily age of Anguilla japonica Temminck and Schlegel elvers from the estuaries of Taiwan with reference to unit stock and larval migration. J Fish Biol 40:845-857

Tzeng WN, Tsai YC (1994) Changes in otolith microchemistry of the Japanese eel, Anguilla japonica, during its migration from the ocean to the rivers of Taiwan. J Fish Biol 45:671-684

Tzeng WN, Cheng PW, Lin FY (1995) Relative abundance, sex ratio and population structure of the Japanese eel Anguilla japonica in Tanshui River system of northern Taiwan. J Fish Biol 46:183-201

Tzeng WN, Shiao JC, lizuka Y (2002) Use of otolith Sr:Ca ratios to study the riverine migratory behaviours of Japanese eel Anguilla japonica. Mar Ecol Progr Ser 245:213-221

Tzeng WN, Tseng YH, Han YS, Hsu CC, Chang CW, Di Lorenzo E, Hsieh CH (2012) Evaluation of multi-scale climate effects on annual recruitment levels of the Japanese eel, Anguilla japonica, to Taiwan. PLOS ONE 7:e30805

Umezawa A, Tsukamoto K, Tabeta O, Yamakawa H (1989) Daily growth increments in the larval otolith of the Japanese eel, Anguilla japonica. Ichthyol Res 35:440-444 van Ginneken V, Ballieux B, Willemze R, Coldenhoff K, Lentjes E, Antonnissen E, Haenen O, van den Thillart G (2005) Hematology patterns of migrating European eels and the role of EVEX virus. Compar Biochem Phys C 140:97-102 van Ginneken V, Bruijs M, Murk T, Palstra A, van den Thillart G (2009) The effects of PCBs on the spawning migration of the European silver eel. In: van den Thillart G, Dufour S, Cliff Rankin J (eds) Spawning migration of the European eel. Springer, London, pp 365-386

Verreault G, Dumont P, Mailhot Y (2004) Habitat losses and anthropogenic barriers as a cause of population decline for American eel (Anguilla rostrata) in St. Lawrence watershed, Canada. In: 2004 ICES Annual Science Conference, Vigo, 22-25 September 2004. ICES, Copenhagen

Wang CH, Tzeng WN (1998) Interpretation of geographic variation in size of American eel, Anguilla rostrata (Le Sueur), elvers on the Atlantic coast of North America by their life history and otolith ageing. Mar Ecol Progr Ser 168:35-43

Wang CH, Tzeng WN (2000) The timing and growth rates of American and European eel leptocephali: a mechanism of larval segregative migration. Fish Res 46:191-205

Watanabe S, Aoyama J, Miller MJ, Ishikawa S, Feunteun E, Tsukamoto K (2008) Evidence of population structure in the giant mottled eel, Anguilla marmorata, using total number of vertebrae. Copeia 2008:680-688

Watanabe S, Miller MJ, Aoyama J, Tsukamoto K (2009) Morphological and meristic evaluation of the population structure of Anguilla marmorata across its range. J Fish Biol 74:2069-2093

Winter HV, Jansen HM, Breukelaar AW (2007) Silver eel mortality during downstream migration in the River Meuse, from a population perspective. ICES J Mar Sci 64:1444-1449

Zenimoto K, Kitagawa T, Miyazaki S, Sasai Y, Kimura S (2009) The effects of seasonal and interannual variability of oceanic structure in the western Pacific North Equatorial Current on larval transport of the Japanese eel Anguilla japonica. J Fish Biol 74:1878-1890

doi:10.1186/1810-522X-52-30

Cite this article as: Leander et al.: Effects of metamorphosis timing and the larval growth rate on the latitudinal distribution of sympatric freshwater eels, Anguilla japonica and A. marmorata, in the western North Pacific. Zoological Studies 2013 52:30.

\section{Submit your manuscript to a SpringerOpen ${ }^{\odot}$ journal and benefit from:}

- Convenient online submission

Rigorous peer review

- Immediate publication on acceptance

- Open access: articles freely available online

- High visibility within the field

- Retaining the copyright to your article

Submit your next manuscript at $>$ springeropen.com 